\title{
Effect of Some Applications on the Performance of Mandarin Trees under Soil Salinity Conditions
}

\author{
Nadia A. Hamed*, R.A. Abdel-Aziz *and Nesreen H. Abou-Baker** \\ ${ }^{*}$ Citrus Research Department, Horticulture Research Institute, Agriculture Research \\ Centre and ${ }^{* *}$ Soils and Water Use Department, National Research Centre, Cairo, \\ Egypt.
}

\begin{abstract}
THE RESPONSE of "Murcott" mandarin trees grown on salt affected soil to different amendments that alleviate salinity stress was studied. The present study was carried out in a private orchard located at "El-Adlia Association", El-Sharqia Governorate, Egypt, during two successive seasons (2014/2015 and 2016/2017). Nine different treatments were used as follow: Potassium silicate (PSat500 and 1000ppm), Magnetite (Mag) at a rate of $58 \mathrm{~kg} / \mathrm{fed} /$ year, Mag + PS at 500, Mag + PSat 1000, Unisale at a rate of $7.9 \mathrm{~L} /$ fed., Unisale + PS at 500, and Unisale + PS at $1000 \mathrm{ppm}$ beside control (Uniform fertilizer program). These different treatments mitigated salinity stress and increased root distribution, photosynthetic pigments, leaves minerals contents, fruit yield and quality of Murcott trees compared with control. The highest yield was obtained by Unisale followed in descending order by PS at $500 \mathrm{ppm}$ and Magnetite treatment. Proline accumulation in fresh leaves, soil pH and EC at the end of the two seasons also were recorded.
\end{abstract}

Keywords: Salinity stress, Mandarin, Silicate, Magnetite, Unisale.

\section{Introduction}

Murcott mandarin is one among the popular citrus fruits in Egypt. According to the Central Administration of Horticulture and Agricultural Crops 2015 report the total mandarin cultivated area is 115083 fed. and the total production is 939767 ton. The major cultivated area is concentrated in the newly reclaimed lands which are committed with some stress conditions such as salinity and drought.

Salinity stress depresses plant growth and development at different physiological levels. The mechanisms by which salt stress damage plants are still a discussing matter due to very complex nature of the salt stress in plants (Zhu, 2001). The content of chlorophyll-a, b, total chlorophyll $(\mathrm{a}+\mathrm{b})$ and carotenoids were decreased with aggravated salt stress (Hussein et al., 2015), due to enzymatic chlorophyll degradation (Kishor, 1995). The resistance to salt stress has been found due to the enhancement of enzymes such as SOD (superoxide dismutase) and catalase, preventing membrane oxidative damage (Zhu et al., 2004).
Silicon ( $\mathrm{Si}$ ) is a beneficial element for plant growth. It helps plants to overcome multiple stresses including biotic and abiotic stresses. Silicon, also, alleviates the effects of other abiotic stresses including salt stresses, metal toxicity, drought stress, radiation damage, nutrient imbalance, high temperature and freezing (Ma et al., 2004). Potassium is the primary osmolyte ion is involved in plant cell membrane dynamics, including the regulation of stomata and the maintenance of turgor and osmotic equilibrium. It plays important roles in the activation and regulation of the enzyme activities (Hopkins, 2006).

On the other hand, calcium and boron are essential mineral nutrient involved in growth and development processes of the plants. There are several physiological processes, which are greatly affected by $\mathrm{Ca}$ and $\mathrm{B}$ nutritional status as cell extension, cell wall stabilization, signal transduction, membrane transport and pollination process (Erdoghan, 2003). 
Magnetite is a natural row rock that hasvery high iron content, a black or brownish-red colorandis'thardness is about 6 Mohs. It is, one of two natural row rocks in the world that are naturally magnetic (Mansour, 2007).

The objectives of this investigation are to study the response of root distribution, photosynthetic pigments and mineral status of leaves, fruit yield and quality of Murcott trees to potassium silicate, calcium and boron (the main components of Unisale), magnetite and their combination added either by spraying or as soil amendments under salinity stress condition.

\section{Materials and Methods}

The present study was carried out during two successive (on) seasons of 2014/ 2015and $2016 / 2017$ in a private citrus orchard located at "El-Adlia Association", El-Sharqia Governorate, Egypt. Five years old Murcott mandarin trees (Citrus sinensis(L.) Osbeck $\times$ Citrus reticulate Blanco) budded on Volkamer lemon rootstock (Citrus volkmeriana Tan and Pasq.) grown in sandy soil cultivated at $3 \times 6 \mathrm{~m}$ apart, under drip irrigation system were used for this study.

The initial soil samples were collected from three depths $(0-20,20-40$ and $40-60 \mathrm{~cm})$ and analyzed for physical and chemical characteristics (Table 1). Analysis of some chemical features of the irrigation water is presented in (Table2). At the end of the two seasons, soil samples were collected from two depths $0-30 \mathrm{~cm}$ (A) and 30$60 \mathrm{~cm}$ (B) to determine the electrical conductivity EC $\left(\mathrm{dSm}^{-1}\right)$ and soil-pH as described by Klute (1986) and Page et al. (1982).

In the two experimental seasons, Magnetite and Unisale were used as soil application, while potassium silicate which was applied as foliar application as follows: 1) Usual fertilization program for the whole orchard (Control), 2) Potassium silicate at the rate of $500 \mathrm{ppm}$ (PS 500), 3) Potassium silicate at the rate of $1000 \mathrm{ppm}$ (PS1000), 4) Magnetite at $58 \mathrm{~kg} / \mathrm{fed} /$ year (Mag), 5) Magnetite at $58 \mathrm{~kg} / \mathrm{fed} / \mathrm{year}$ plus PS at 500,6) Magnetite at $58 \mathrm{~kg} / \mathrm{fed} /$ year plus PS at $1000 \mathrm{ppm}$, 7) Unisale $(8 \% \mathrm{Ca}+0.5 \% \mathrm{~B})$ at rate of $7.9 \mathrm{~L} / \mathrm{fed}$ 8) Unisale at $7.9 \mathrm{~L} /$ fed plus PS at 500,9 ) Unisale at $7.9 \mathrm{~L} /$ fed plus PS at $1000 \mathrm{ppm}$.

All treatments were applied at the second week of March, the second week of May and July.
Magnetite was added as one application/ year. Control treatment was sprayed with water. The following parameters were recorded.

\section{Fruit yield}

Yield was determined at harvesting stage (the second week of February) under the experimental condition and number of fruits per tree was counted, the fruit weight was measured and the final yield (ton/fed.) was calculated.

\section{Fruit quality}

At harvest stage, representative samples of 10 fruits were taken from each tree (replicate) and the following characters were determined:

\section{Fruit physical characteristics}

Average fruit number/tree, average fruit weight $(\mathrm{g})$, fruit size $\left(\mathrm{cm}^{3}\right)$, fruit length $(\mathrm{cm})$, fruit diameter $(\mathrm{cm})$, fruit shape index (length/diameter ratio), fruit firmness (1.b/ inches $\left.{ }^{2}\right)$ and fruit peel thickness $(\mathrm{cm})$ were measured.

\section{Fruit chemical properties}

Total soluble solids (T.S.S. \%) of fruit juice was determined by a hand refractometer, total acidity percentage (expressed as $\mathrm{mg}$ citric acid/100 $\mathrm{cm}^{3}$ juice) was determined as outlined in A.O.A.C. (1995), total soluble solids/acidity ratio was obtained from dividing the percentages of total soluble solids by the values of total acidity. Vitamin C (as mg ascorbic acid was determined per $100 \mathrm{ml}$ fruit juice) according to A.O.A.C. (1995).

\section{Leaf photosynthetic pigments}

Fresh leaves were extracted with dimethyl formamide (D.M.F) solution $\left[\mathrm{HCON}\left(\mathrm{CH}_{3}\right)_{2}\right]$ and placed overnight at cool temperature $\left(5^{\circ} \mathrm{C}\right)$. Chlorophyll $\mathrm{a}$ and $\mathrm{b}$ as well as carotenoids were measured by spectrophotometer at wave lengths 663,647 and $470 \mu \mathrm{m}$, respectively according to the equations described by Nornai (1982) and calculated as follow:-

$$
\begin{aligned}
& \text { Chl. } \mathrm{a}=12.70 \mathrm{~A}_{663}-2.79 \mathrm{~A}_{647} \\
& \text { Chl. } \mathrm{b}=20.76 \mathrm{~A}_{647}-4.62 \mathrm{~A}_{663} \\
& \text { Total chl. }=17.90 \mathrm{~A}_{647}+8.08 \mathrm{~A}_{663} \\
& \text { Total carotenoids }=\left[1000 \times \mathrm{A}_{470}(-3.72 \mathrm{Chl} . \mathrm{a}-\right. \\
& 104 \mathrm{Chl} . \mathrm{b})] / 229
\end{aligned}
$$


TABLE 1. Some physical and chemical properties of the studied soils

\begin{tabular}{lccc}
\hline Characteristics & $\mathbf{0 - 2 0} \mathbf{~ c m}$ & $\mathbf{2 0 - 4 0} \mathbf{~ c m}$ & $\mathbf{4 0 - 6 0} \mathbf{~ c m}$ \\
\hline $\mathrm{pH}(1: 2.5$ soil : water ratio) & 7.81 & 7.97 & 8.03 \\
EC (1:5 soil : water ratio) dSm ${ }^{-1}$ & 6.10 & 3.7 & 2.7 \\
\hline Soluble cations (m.eq/L): & & & \\
\hline Calcium & 16.0 & 12.5 & 6.3 \\
Magnesium & 7.2 & 5.7 & 4 \\
Potassium & 0.4 & 0.4 & 16.3 \\
Sodium & 37.4 & 18.4 & - \\
\hline Soluble anions (m.eq/L): & & & 2.8 \\
\hline Carbonate & - & - & 15.5 \\
Bicarbonate & 1.9 & 2.7 & 8.7 \\
Chloride & 54.7 & 28.2 & \\
Sulphate & 4.4 & 6.1 & 38.7 \\
\hline Physical properties (\%): & & & 46.5 \\
\hline Coarse sand & 41.7 & 40.6 & 12.3 \\
Fine sand & 44.3 & 44.5 & 2.5 \\
Silt & 11.6 & 10.7 & Sandy \\
Clay & 2.4 & 4.2 & \\
Textural class & Sandy & Sandy & \\
\hline
\end{tabular}

TABLE 2. Some chemical analysis of irrigation water

\begin{tabular}{|c|c|c|c|c|c|c|c|c|c|}
\hline \multirow{2}{*}{ pH } & \multirow{2}{*}{$\begin{array}{c}\text { EC } \\
\text { dSm }^{-1}\end{array}$} & \multicolumn{8}{|c|}{ Cations and anions ( $\mathrm{g} / \mathrm{l})$} \\
\hline & & $\mathbf{N a}^{+}$ & $\mathbf{K}^{+}$ & $\mathbf{C a}^{++}$ & $\mathbf{M g}^{++}$ & $\mathrm{CO}_{3}^{--}$ & $\mathrm{HCO}_{3}^{-}$ & $\mathrm{Cl}^{-}$ & $\mathrm{SO}_{4}^{-}$ \\
\hline 8.39 & 0.48 & 1.9 & 0.2 & 1.6 & 1.1 & - & 2.3 & 1.8 & 0.7 \\
\hline
\end{tabular}

\section{Leaf mineral content}

Forty leaves (third leaf or fourth) of six months old of non-fruiting and non-flushing shoots, were collected according to Jones and Embleton (1960) to determine N,P,K and $\mathrm{Na}$ concentration in dried leaves expressed as $\%$ of dry weight. Total nitrogen (\%) was determined using Microkjeldahl method. Phosphorus (\%) was determined calorimetrically using ammonium metavanadate method. Potassium and sodium (\%) was determined using the flame photometric method. All mentioned elements were measured as described by Cottenie et al. (1982). The ratio of $\mathrm{Na} / \mathrm{K}$ was calculated.

\section{Proline concentration}

Leaf proline concentration ( $\mu \mathrm{mol} / \mathrm{g}$ dry weight) was determined calorimetrically as described by Bates et al. (1973) modified and adapted accordingly Naqvi et al. (2002).
Root horizontal extension and vertical penetration $(m)$ and horizontal/vertical root ratio

The maximum vertical root penetration in soil at $100 \mathrm{~cm}$ from tree trunk was determined. The maximum horizontal root extension from tree trunk (average of the four tree directions) was measured and expressed in meter and the horizontal/vertical root ratio was calculated (Newman, 1966).

Experimental design and statistical analysis

The complete randomize block design (CRBD) of nine treatments and three replicates (three trees/each) with total number 81 trees. The obtained data was statistically analyzed using the Statistical Analysis System (SASM-Agri). The multiple comparisons of means were performed according to Duncan test (Duncan, 1955 and Snedecor \& Cochran, 1980). 


\section{$\underline{\text { Results and Discussions }}$}

\section{Fruit yield}

It is evident from the data obtained in Table 3 that, using Unisale (7.9 liter/fed), magnetite (58 $\mathrm{kg} / \mathrm{fed} /$ year) as ground application or spraying the trees with potassium silicate (500 ppm) had significant promotion on the number of fruit per tree, the average of fruit weight and the final yield (ton/fed) compared with control treatment in both experimental seasons. The highest yield (7.23, 7.16 and 7.47, 6.37 ton/fed) were obtained by Unisale added as ground application (7.9 liter/fed) and potassium silicate sprayed at $(500 \mathrm{ppm})$ in both seasons, respectively followed by magnetite $(58 \mathrm{~kg} / \mathrm{fed} / \mathrm{year})$ and the other combination treatments.

In this respect, several investigations showed that $\mathrm{Ca}$ and $\mathrm{B}$ (Unisale) have simulative effects effect on ammonium absorption and thus increase the amino acids and protein concentration, and thereby affecting cell elongation and division, structure and permeability of cell membranes and carbohydrate translocations which is directly reflect on the yield parameters such as number of fruit per tree, fruit weight and the final tree yield (López-Lefebre et al., 2002, White, 2000 and Ahmed et al., 1996). Fidalski et al. (2000) mentioned that, orange fruit weight was positively related to leaf $\mathrm{Ca}$ and soil $\mathrm{Ca}$ in the fertilized rows of high productivity orchards. The results showed nutritional problems associated with $\mathrm{Ca}, \mathrm{Mg}$ and $\mathrm{Zn}$ deficiency in the low productivity orchards, and suggested the need for $\mathrm{K}$ treatments, as well as $\mathrm{Zn}$ supply. Jackson (2001) reported that, calcium is the predominating element in citrus trees.

Also, previous studies showed that using silicon improve water transportation, and the nutritional status of the plant which directly reflected on the fruit yield (Matichenkov et al., 2000 and Ibrahim and Al-Wasfy, 2014). On the other hand,Snyder (1999) reported that, application of silicon fertilizer accelerated citrus growth, fruit maturation by 2 to 4 weeks, and improved fruit quantity. In addition, Obreza (2003) reported that, potassium is important for fruit formation and enhances fruit size, flavor and color.

Moreover, Mansour (2007) found that Magnetite might have a stimulating effect on plant growth and the absorption of N, P, K, and $\mathrm{Ca}$ and consequently improving the final yield.

\section{Fruit quality \\ Fruit physical characteristics}

Table 4 showed significant differences in the fruit physical properties i.e. fruit size, fruit firmness and peel thickness due to applied treatments. Concerning fruit size data indicated that addition of Unisale either individually or in combination with potassium silicate at 1000 ppm followed by potassium silicate $1000 \mathrm{ppm}$ alone resulted in the higher fruit size without significant differences among them in the first season. While in the second season the use of magnetite occupied the second position followed by potassium silicate $1000 \mathrm{ppm}+$ Unisale and potassium silicate $500 \mathrm{ppm}$.

TABLE 3. Effect of some applications on Murcott mandarin fruits yield in the two experimental seasons

\begin{tabular}{lcccccc}
\hline \multirow{2}{*}{ Treatments } & \multicolumn{2}{c}{ Fruit number/tree } & \multicolumn{2}{c}{ Fruit weight $(\mathbf{g})$} & \multicolumn{2}{c}{ Fruit yield (ton/fed) } \\
\cline { 2 - 7 } & $\mathbf{1}^{\text {st }}$ & $\mathbf{2}^{\text {nd }}$ & $\mathbf{1}^{\text {st }}$ & $\mathbf{2}^{\text {nd }}$ & $\mathbf{1}^{\text {st }}$ & $\mathbf{2}^{\text {nd }}$ \\
\hline Control & $79.7 \mathrm{c}$ & $80.0 \mathrm{c}$ & $144.0 \mathrm{c}$ & $103.8 \mathrm{c}$ & $1.86 \mathrm{c}$ & $1.40 \mathrm{c}$ \\
PS 500 ppm & $230.7 \mathrm{a}$ & $235.0 \mathrm{a}$ & $167.7 \mathrm{a}$ & $166.7 \mathrm{a}$ & $7.16 \mathrm{a}$ & $6.37 \mathrm{a}$ \\
PS 1000 ppm & $90.0 \mathrm{bc}$ & $96.7 \mathrm{bc}$ & $172.3 \mathrm{a}$ & $117.7 \mathrm{c}$ & $2.47 \mathrm{bc}$ & $1.87 \mathrm{bc}$ \\
Mag & $214.0 \mathrm{a}$ & $186.7 \mathrm{~b}$ & $165.3 \mathrm{~b}$ & $182.7 \mathrm{a}$ & $6.95 \mathrm{a}$ & $5.68 \mathrm{a}$ \\
Mag+ PS 500 & $79.0 \mathrm{c}$ & $83.3 \mathrm{bc}$ & $146.7 \mathrm{c}$ & $145.3 \mathrm{~b}$ & $3.96 \mathrm{~b}$ & $2.02 \mathrm{bc}$ \\
Mag+ PS 1000 & $129.5 \mathrm{~b}$ & $132.7 \mathrm{~b}$ & $154.7 \mathrm{bc}$ & $122.7 \mathrm{c}$ & $4.15 \mathrm{~b}$ & $2.69 \mathrm{~b}$ \\
Unisale & $239.7 \mathrm{a}$ & $243.3 \mathrm{a}$ & $182.7 \mathrm{a}$ & $185.8 \mathrm{a}$ & $7.23 \mathrm{a}$ & $7.47 \mathrm{a}$ \\
Unisale+PS500 & $187.0 \mathrm{~b}$ & $193.3 \mathrm{ab}$ & $164.0 \mathrm{~b}$ & $140.6 \mathrm{~b}$ & $5.08 \mathrm{a}$ & $4.38 \mathrm{~b}$ \\
Unisale+ PS1000 & $175.0 \mathrm{~b}$ & $181.7 \mathrm{~b}$ & $177.3 \mathrm{a}$ & $162.8 \mathrm{a}$ & $3.06 \mathrm{~b}$ & $4.93 \mathrm{~b}$ \\
\hline
\end{tabular}

Egypt. J. Hort. Vol. 44, No. 2 (2017) 
In contrary, in the second season the Unisale significantly registered second level in fruit firmness, while the higher results were achieved with all potassium silicate treatments either alone or in combinations with magnetite and Unisale compared with the control treatment. As regarding to peel thickness, in the second season, the Unisale either alone or in combination with potassium silicate $(1000 \mathrm{ppm})$ was recorded the highest values when compared with control treatment. Concerning, fruit shape index, there were no significant differences among all treatments.

In this respect, Ladaniya (2008) reported that, potassium is considered indispensable in consistent production of good quality citrus fruits. Its deficiency not only reduces yields but results in smaller fruit size, soft and thin peels, and increased decay. Ibrahim and Al-Wasfy (2014) revealed that, using silicon and/ or potassium on Valencia orange effectively enhanced the fruit physical characteristics. Silicon has been shown to induce resistance against both abiotic and biotic stresses in several agronomic plants (Ma and Yamaji, 2006).

Ganeshamrthy et al. (2011) found that, high rate of $\mathrm{K}(100 \%)$ is needed to achieve not only highest total fruit production but also the greatest percentage of fruit production which is suitable for marketing with good quality. Applied $\mathrm{K}$ (from 50 to $100 \%$ ) influenced fruit size of mango, banana, citrus, guava, papaya, grapes and pineapple, appearance and color and consumer like fruit recovery, aroma and taste. Moreover, the results agreed with those obtained by Fatma and Abd-Eladl (2017) on Valencia orange.

\section{Fruit chemical characteristics}

Data in Table 5 reveals that, TSS/acid ratio was significantly increased by the investigated silicate spray $(500 \mathrm{ppm})$ and /or magnetite treatments during the both seasons. Such trend was true in total soluble solids at the first season. While, total acidity significantly decrease was detected by ground application with Unisale treatment when compared with control treatment at the two experimental seasons.

Regarding to V.C the data showed that no constant trend could be detected among all treatments. Silicate is accumulated primarily in epidermal tissue in both roots and leaves as polymerized silicagel and is associated with pectin and calcium ions (Waterkeyn et al.,1982).

In this respect, Saure (2005) reported that, calcium is a vital macronutrient in plant cycle including fruit development and securing of good fruit quality. Lack of Ca might cause an abnormal growth in fruit and its low mobility into fruit make $\mathrm{Ca}$ concentration in fruit decreasing as the fruit grows. Also, Spiegel - Roy and Goldschmidt (2008) mentioned that, $\mathrm{K}$ acts as an osmotic agent in the opening and closing of stomata. It plays an important role in controlling the acidity of the citrus fruit juice. It functions in charge balancing and membrane transport.

Ganeshamurthy et al. (2011) reported that, fruit size, appearance, color, soluble solids, acidity, vitamin has been influenced by photosynthesis, translocation of photosynthats, regulation of stomata, activation of enzymes and many other processes. Potassium's role is in water regulation of the plants and tolerance to environmental stresses such as drought, excess water, wind high and low temperature is related to productivity of the trees and quality of fruit crops (mango, apple, citrus, pineapple, grapes, sapota and banana).

TABLE 4. Effect of some applications on physical properties of Murcott mandarin fruits in the two experimental seasons

\begin{tabular}{|c|c|c|c|c|c|c|c|c|}
\hline \multirow{2}{*}{ Treatments } & \multicolumn{2}{|c|}{$\begin{array}{c}\text { Fruit size } \\
\left(\mathrm{cm}^{3}\right)\end{array}$} & \multicolumn{2}{|c|}{$\begin{array}{c}\text { Fruit firmness } \\
\left(\text { l.b/ inches }{ }^{2}\right)\end{array}$} & \multicolumn{2}{|c|}{ Fruit shape index } & \multicolumn{2}{|c|}{$\begin{array}{c}\text { Peel thickness } \\
(\mathrm{mm})\end{array}$} \\
\hline & $1^{\text {st }}$ & $2^{\text {nd }}$ & $1^{\text {st }}$ & $2^{\mathrm{nd}}$ & $1^{\text {st }}$ & $2^{\mathrm{nd}}$ & $1^{\text {st }}$ & $2^{\text {nd }}$ \\
\hline PS 500 ppm & $179.2 \mathrm{~b}$ & $181.11 \mathrm{a}$ & $10.7 \mathrm{~b}$ & $15.09 \mathrm{a}$ & $0.77 \mathrm{a}$ & $0.78 \mathrm{a}$ & $0.36 \mathrm{a}$ & $0.36 \mathrm{~b}$ \\
\hline PS 1000 ppm & $183.0 \mathrm{a}$ & $132.77 b c$ & $12.9 \mathrm{a}$ & $14.68 \mathrm{a}$ & $0.79 \mathrm{a}$ & $0.81 \mathrm{a}$ & $0.28 \mathrm{~b}$ & $0.34 \mathrm{~b}$ \\
\hline Mag+ PS 1000 & $165.3 \mathrm{~b}$ & $136.11 b c$ & $10.8 \mathrm{~b}$ & $14.12 \mathrm{a}$ & $0.78 \mathrm{a}$ & $0.79 \mathrm{a}$ & $0.25 \mathrm{c}$ & $0.35 \mathrm{ab}$ \\
\hline Unisale & $194.3 \mathrm{a}$ & $201.25 \mathrm{a}$ & $10.9 \mathrm{~b}$ & $11.86 \mathrm{~b}$ & $0.76 \mathrm{a}$ & $0.77 \mathrm{a}$ & $0.28 \mathrm{~b}$ & $0.41 \mathrm{a}$ \\
\hline Unisale+PS500 ppm & $176.0 \mathrm{~b}$ & $160.00 \mathrm{~b}$ & $11.0 \mathrm{~b}$ & $12.84 \mathrm{~b}$ & $0.77 \mathrm{a}$ & $0.79 \mathrm{a}$ & $0.30 \mathrm{~b}$ & $0.32 \mathrm{c}$ \\
\hline Unisale+PS1000 ppm & $190.5 \mathrm{a}$ & $185.00 \mathrm{a}$ & $12.3 \mathrm{a}$ & $11.28 \mathrm{~b}$ & $0.79 \mathrm{a}$ & $0.82 \mathrm{a}$ & $0.26 \mathrm{c}$ & $0.39 \mathrm{a}$ \\
\hline
\end{tabular}


TABLE 5. Effect of some applications on chemical properties of Murcott mandarin fruits in the two experimental seasons

\begin{tabular}{|c|c|c|c|c|c|c|c|c|}
\hline \multirow{2}{*}{ Treatments } & \multicolumn{2}{|c|}{ TSS (\%) } & \multicolumn{2}{|c|}{ Acidity(\%) } & \multicolumn{2}{|c|}{ TSS/Acid ratio } & \multicolumn{2}{|c|}{$\begin{array}{c}\text { Vit. C.(mg/100ml } \\
\text { juice) }\end{array}$} \\
\hline & $1^{\text {st }}$ & $2^{\text {nd }}$ & $1^{\text {st }}$ & $2^{\text {nd }}$ & $1^{\text {st }}$ & $2^{\text {nd }}$ & $1^{\text {st }}$ & 2 nd \\
\hline Control & $10.83 \mathrm{c}$ & $12.83 \mathrm{a}$ & $0.96 \mathrm{~b}$ & $0.96 \mathrm{a}$ & $11.28 \mathrm{c}$ & $13.37 \mathrm{c}$ & $48.6 \mathrm{a}$ & $51.10 \mathrm{a}$ \\
\hline PS $500 \mathrm{ppm}$ & $12.67 \mathrm{a}$ & $12.00 \mathrm{a}$ & $0.99 \mathrm{ab}$ & $0.82 \mathrm{bc}$ & $12.93 \mathrm{a}$ & $14.91 \mathrm{a}$ & $36.9 \mathrm{c}$ & $39.90 \mathrm{~b}$ \\
\hline PS 1000 ppm & $11.67 \mathrm{ab}$ & $12.67 \mathrm{a}$ & $0.99 \mathrm{ab}$ & $1.02 \mathrm{a}$ & $11.73 \mathrm{~b}$ & $12.50 \mathrm{ab}$ & $48.6 \mathrm{a}$ & $48.30 \mathrm{a}$ \\
\hline Mag & $11.50 \mathrm{ab}$ & $11.33 \mathrm{c}$ & $0.97 \mathrm{~b}$ & $0.76 \mathrm{c}$ & $12.07 \mathrm{a}$ & $15.41 \mathrm{a}$ & $40.5 \mathrm{~b}$ & $37.80 \mathrm{c}$ \\
\hline Mag+ PS 500 & $12.50 \mathrm{a}$ & $12.17 \mathrm{a}$ & $1.14 \mathrm{a}$ & $0.89 \mathrm{~b}$ & $10.94 \mathrm{c}$ & $13.65 b c$ & $40.5 \mathrm{~b}$ & $42.00 \mathrm{~b}$ \\
\hline Mag+ PS1000 & $12.33 \mathrm{a}$ & $11.67 \mathrm{~b}$ & $1.04 \mathrm{a}$ & $0.86 \mathrm{~b}$ & $11.93 \mathrm{~b}$ & $13.62 \mathrm{c}$ & $40.5 \mathrm{~b}$ & $49.00 \mathrm{a}$ \\
\hline Unisale & $11.33 \mathrm{~b}$ & $11.33 \mathrm{c}$ & $0.92 \mathrm{c}$ & $0.78 \mathrm{bc}$ & $12.36 \mathrm{a}$ & $14.51 \mathrm{a}$ & $46.8 \mathrm{~b}$ & $39.90 \mathrm{~b}$ \\
\hline Unisale+PS500 ppm & $11.33 \mathrm{~b}$ & $12.33 \mathrm{a}$ & $0.94 \mathrm{~b}$ & $0.89 \mathrm{~b}$ & $12.09 \mathrm{a}$ & $13.81 \mathrm{~b}$ & $43.2 \mathrm{bc}$ & $38.50 \mathrm{~b}$ \\
\hline Unisale+PS1000 ppm & $11.50 \mathrm{ab}$ & $11.67 \mathrm{~b}$ & $1.04 \mathrm{a}$ & $0.87 \mathrm{~b}$ & $11.04 \mathrm{~b}$ & $13.83 \mathrm{~b}$ & $46.8 \mathrm{~b}$ & $40.60 \mathrm{~b}$ \\
\hline
\end{tabular}

Generally, our results regarding the beneficial effect of spraying trees with silicate spraying and magnetite amendments on some fruit chemical characteristics goes partially with the findings of Ibrahim and AlWasfy (2014) on Valencia orange and Thippeshappa et al. (2014) and Lalithya et al. (2014) on Sapota.

\section{Plant pigments}

Data presented in Table 6 showed the effect of the tested treatments on the mandarin leaf pigments i.e. chlorophyll $\mathrm{a}, \mathrm{b}$ and carotene in both experimental seasons. The data clarified that clear significant differences were obtained by using ground application with Unisale (7.9 liter/fed) and Magnetite (58 kg/fed/ year) in comparison with the control in both seasons. The highest values of chlorophyll $\mathrm{a}, \mathrm{b}$ and total chlorophyll were obtained with the use of Unisale as ground application in both seasons. The same trend was shown in chlorophyll a and total chlorophyll when Magnetite or Unisale+ PS at $500 \mathrm{ppm}$ were used. While, the higher values of total carotene were obtained by using Mag.+PS at $1000 \mathrm{ppm}$. On the other hand, there were no significant differences among the other tested treatments.

An improvement in the second season was observed by using some combination of treatments such as Mag alone, (Mag + PS 500 ppm) and (Unisale + PS at 500 ppm). Epstein (1999) and Datnoff et al. (2001) reported that, silicon application increase leaf chlorophyll content and plant metabolism. Also, Mervat et al. (2013) found that, total chlorophyll content in the leaves of grapevines was positively affected by the application of Unisale or magnetic iron, compared to the control.

Calcium and boron are playing a key role in cross-linking acidic pectin residues and in the cellular membrane system and thus its importance for the enhancement of leaves pigments (Peter, 2005). Calcium ions control the activity not only of ion transporters but also of many other proteins, either directly or indirectly which is important for the enhancement of leaves pigments (via $\mathrm{Ca}^{2+}$ binding factors) (Plieth, 2005).

Moreover, Jia et al. (1998) working on (Citrus limon) seedlings, found that inadequate or excessive $\mathrm{B}$ and $\mathrm{Ca}$ decreased chlorophyll content and photosynthetic rate. With a Ca: B ratio of 491 in the leaf at $\mathrm{pH}$ 7.6-7.8, chlorophyll reached its maximum; and with a Ca: B ratio of 525 in the leaf at $\mathrm{pH} 5.6-5.8$ or of 285 at $\mathrm{pH}$ 7.6-7.8. Moreover, it is well known that silicon and potassium are playing important role in growth improvement, photosynthesis increase and chlorophyll concentration per leaf area since they are involved in the metabolic process of the plants (Hwang et al., 2005 and Khan et al., 1994).

The results were consistent with those attained by Agarie (1996) who showed that, the reduction and/or the excessive of silica caused reduction in the amount of chlorophyll. As a result, plant photosynthesis will be reduced. They related the reason for this issue to silica role in photosynthesis chain and preventing chlorophyll degradation by silica. Also, Snyder et al. (1999) reported that, silicon has been shown to result in higher concentrations of chlorophyll per unit area of leaf tissue. This action may mean that a plant can tolerate either low or high light levels by using light more efficiently. Moreover, supplemental levels of soluble silicon are responsible for producing higher concentrations of the enzyme ribulose biphosphate carboxylase in leaf tissue. This enzyme regulates the metabolism of $\mathrm{CO}_{2}$ and promotes more efficient use of $\mathrm{CO}_{2}$ by plants. 
TABLE 6. Effect of some applications on plant pigments (mg/g f.wt.) of Murcott mandarin leaves in the two experimental seasons

\begin{tabular}{lcccccccc}
\hline \multirow{2}{*}{ Treatments } & \multicolumn{2}{c}{ Chl. (a) } & \multicolumn{2}{c}{ Chl. (b) } & \multicolumn{2}{c}{ Total chl. } & \multicolumn{2}{c}{ Total carotene } \\
\cline { 2 - 8 } & $\mathbf{1}^{\text {st }}$ & $\mathbf{2}^{\text {nd }}$ & $\mathbf{1}^{\text {st }}$ & $\mathbf{2}^{\text {nd }}$ & $\mathbf{1}^{\text {st }}$ & $\mathbf{2}^{\text {nd }}$ & $\mathbf{1}^{\text {st }}$ & $\mathbf{2}^{\text {nd }}$ \\
\hline Control & $0.59 \mathrm{c}$ & $0.70 \mathrm{c}$ & $0.25 \mathrm{c}$ & $0.38 \mathrm{c}$ & $0.84 \mathrm{~b}$ & $1.08 \mathrm{c}$ & $0.12 \mathrm{~b}$ & $0.11 \mathrm{~b}$ \\
PS 500 ppm & $0.66 \mathrm{~b}$ & $0.77 \mathrm{~b}$ & $0.32 \mathrm{c}$ & $0.53 \mathrm{~b}$ & $0.98 \mathrm{~b}$ & $1.30 \mathrm{~b}$ & $0.09 \mathrm{c}$ & $0.08 \mathrm{bc}$ \\
PS 1000 ppm & $0.71 \mathrm{~b}$ & $0.77 \mathrm{~b}$ & $0.35 \mathrm{bc}$ & $0.42 \mathrm{~b}$ & $1.07 \mathrm{ab}$ & $1.22 \mathrm{~b}$ & $0.12 \mathrm{~b}$ & $0.10 \mathrm{bc}$ \\
Mag & $0.75 \mathrm{a}$ & $0.84 \mathrm{a}$ & $0.44 \mathrm{~b}$ & $0.67 \mathrm{~b}$ & $1.18 \mathrm{a}$ & $1.50 \mathrm{a}$ & $0.13 \mathrm{~b}$ & $0.11 \mathrm{~b}$ \\
Mag+ PS 500 ppm & $0.73 \mathrm{~b}$ & $0.76 \mathrm{~b}$ & $0.33 \mathrm{c}$ & $0.44 \mathrm{~b}$ & $1.19 \mathrm{a}$ & $1.20 \mathrm{~b}$ & $0.12 \mathrm{~b}$ & $0.08 \mathrm{bc}$ \\
Mag+ PS1000 ppm & $0.67 \mathrm{bc}$ & $0.83 \mathrm{a}$ & $0.35 \mathrm{bc}$ & $0.69 \mathrm{a}$ & $1.02 \mathrm{ab}$ & $1.52 \mathrm{a}$ & $0.17 \mathrm{a}$ & $0.14 \mathrm{a}$ \\
Unisale & $0.83 \mathrm{a}$ & $0.83 \mathrm{a}$ & $0.61 \mathrm{a}$ & $0.92 \mathrm{a}$ & $1.44 \mathrm{a}$ & $1.76 \mathrm{a}$ & $0.13 \mathrm{~b}$ & $0.06 \mathrm{c}$ \\
Unisale+PS500 ppm & $0.79 \mathrm{a}$ & $0.84 \mathrm{a}$ & $0.48 \mathrm{~b}$ & $0.67 \mathrm{a}$ & $1.26 \mathrm{a}$ & $1.51 \mathrm{a}$ & $0.13 \mathrm{~b}$ & $0.11 \mathrm{~b}$ \\
Unisale+PS1000 ppm & $0.62 \mathrm{~b}$ & $0.73 \mathrm{~b}$ & $0.29 \mathrm{c}$ & $0.42 \mathrm{~b}$ & $0.91 \mathrm{~b}$ & $1.15 \mathrm{c}$ & $0.12 \mathrm{~b}$ & $0.09 \mathrm{bc}$ \\
\hline
\end{tabular}

Salinity could seriously change the photosynthetic carbon metabolize, leaf chlorophyll content as well as photosynthetic efficiency (Hussein et al., 2015). Generally, all the tested treatments reduced the negative impact of soil salt stress on photosynthetic pigments i.e. chlorophylls and carotenoids which is carry out the functions of reception and storage light mainly in the antenna complexes (Turan et al., 2007).

\section{Nutrients}

The highest significant values of $\mathrm{N} \%$ were obtained by the use of Unisale and its combinations while the use of potassium silicate and its combinations resulted in intermediate values and the lowest was committed with the control in both seasons (Table 7). The same trend was obtained with phosphorus contents. Concerning $\mathrm{K}$ contents, the use of potassium silicate and its combinations induced the highest $\mathrm{K}$ contents in both seasons with significant differences among the other tested treatments. The results of $\mathrm{Na}$ contents showed insignificant differences in both seasons. Moreover, the tested treatments showed significant differences in the ratio of $\mathrm{Na} / \mathrm{K}$ where the highest results were obtained with the use of Unisale and its combinations, potassium silicate and magnetite in both seasons (Fig.1). Increasing $\mathrm{K}^{+}$concentration shows the ability of treated trees to combat the salinity stress that will strongly depend upon $\mathrm{Na}^{+}$and $\mathrm{Si}$ content. These results are in harmony with those obtained by Ali et al. (2013) who found that N, P, K \% in vineyard leaves were increased by addition of Unisale and Magnetite compared with control.

In this respect,Epstein (1999) and Datnoff et al. (2001) concluded that silicon application mitigated nutrient imbalance this effect was associated with lowering $\mathrm{Na}$ and $\mathrm{Cl}$ translocation.
The efficiency of potassium silicate in enhancing yield and its nutrition status especially under saline condition are referring to several direct and indirect mechanisms; the role of $\mathrm{Si}$ and $\mathrm{K}$ in mitigating the toxic effect of $\mathrm{Na}$ by enhancing K:Na selectivity ratio (Snyder et al., 1999, AbouBaker et al., 2011 and 2012). In addition Si decreases the permeability of plasma membrane and electrolytic leakage of leaf cells (Liang, 1999 and Reezi et al., 2009) and improving the ultrastructure of chloroplasts, photosynthetic activity and plant water status (Shu and Liu, 2001and Romero-Aranda et al., 2006). Deposition of amorphous silica in cell walls limits transpiration hence salt accumulates in roots and reduces its translocation to shoots (Epstein, 1999).

\section{Proline concentration}

Fig. 2 indicated that the values of proline concentration varied from first to second seasons showing significant differences among all the tested treatments. Generally, proline accumulation in leaves was higher in first season than second one. This may be due to increasing soil salinity with adequate and continuously management through two seasons. However, in the second season the lowest values were obtained with the use of Magnetite and its combination treatments without significant differences followed by the use of Unisale or PS at1000 ppm when compared with control treatment. The lower values indicted that those treatments reduced the impact of stress conditions on the plant performance. The obtained results are in harmony with those obtained by Levent et al. (2008) on wheat plants, Dhawi and Al-Khayri (2008) on date palm and Mervat et al. (2013) found that, using Unisale or magnetic iron significantly reduced proline content in leaves of Thompson seedless grapevine comparing to control. 
TABLE 7. Effect of some applications on element concentrations of Murcott mandarin leaves in the two experimental seasons

\begin{tabular}{lcccccccc}
\hline \multirow{2}{*}{ Treatments } & \multicolumn{2}{c}{$\mathbf{N \%}$} & \multicolumn{2}{c}{$\mathbf{P \%}$} & \multicolumn{2}{c}{$\mathbf{K \%}$} & \multicolumn{2}{c}{$\mathbf{N a \%}$} \\
\cline { 2 - 9 } & $\mathbf{1}^{\text {st }}$ & $\mathbf{2}^{\text {nd }}$ & $\mathbf{1}^{\text {st }}$ & $\mathbf{2}^{\text {nd }}$ & $\mathbf{1}^{\text {st }}$ & $\mathbf{2}^{\text {nd }}$ & $\mathbf{1}^{\text {st }}$ & $\mathbf{2}^{\text {nd }}$ \\
\hline Control & $1.75 \mathrm{c}$ & $1.67 \mathrm{c}$ & $0.14 \mathrm{c}$ & $0.15 \mathrm{c}$ & $1.11 \mathrm{a}$ & $1.31 \mathrm{~b}$ & $0.21 \mathrm{a}$ & $0.29 \mathrm{a}$ \\
PS 500 ppm & $1.64 \mathrm{c}$ & $1.93 \mathrm{~b}$ & $0.16 \mathrm{~b}$ & $0.16 \mathrm{~b}$ & $1.11 \mathrm{a}$ & $1.38 \mathrm{a}$ & $0.21 \mathrm{a}$ & $0.29 \mathrm{a}$ \\
PS 1000 ppm & $2.00 \mathrm{a}$ & $1.85 \mathrm{bc}$ & $0.16 \mathrm{~b}$ & $0.16 \mathrm{~b}$ & $1.18 \mathrm{a}$ & $1.41 \mathrm{a}$ & $0.21 \mathrm{a}$ & $0.30 \mathrm{a}$ \\
Mag & $1.95 \mathrm{ab}$ & $1.95 \mathrm{~b}$ & $0.16 \mathrm{~b}$ & $0.16 \mathrm{~b}$ & $1.05 \mathrm{~b}$ & $1.38 \mathrm{a}$ & $0.21 \mathrm{a}$ & $0.28 \mathrm{a}$ \\
Mag+ PS 500 & $1.67 \mathrm{c}$ & $1.77 \mathrm{bc}$ & $0.16 \mathrm{~b}$ & $0.16 \mathrm{~b}$ & $1.18 \mathrm{a}$ & $1.43 \mathrm{a}$ & $0.21 \mathrm{a}$ & $0.31 \mathrm{a}$ \\
Mag+ PS1000 & $1.80 \mathrm{~b}$ & $1.77 \mathrm{bc}$ & $0.16 \mathrm{~b}$ & $0.16 \mathrm{~b}$ & $1.36 \mathrm{a}$ & $1.53 \mathrm{a}$ & $0.21 \mathrm{a}$ & $0.29 \mathrm{a}$ \\
Unisale & $1.98 \mathrm{a}$ & $2.13 \mathrm{a}$ & $0.17 \mathrm{a}$ & $0.17 \mathrm{a}$ & $0.96 \mathrm{~b}$ & $1.06 \mathrm{c}$ & $0.21 \mathrm{a}$ & $0.24 \mathrm{c}$ \\
Unisale+PS500 ppm & $1.98 \mathrm{a}$ & $2.18 \mathrm{a}$ & $0.16 \mathrm{~b}$ & $0.17 \mathrm{a}$ & $0.86 \mathrm{c}$ & $1.18 \mathrm{c}$ & $0.21 \mathrm{a}$ & $0.23 \mathrm{c}$ \\
Unisale+PS1000 ppm & $2.08 \mathrm{a}$ & $2.13 \mathrm{a}$ & $0.16 \mathrm{~b}$ & $0.17 \mathrm{a}$ & $0.96 \mathrm{~b}$ & $1.18 \mathrm{c}$ & $0.21 \mathrm{a}$ & $0.26 \mathrm{~b}$ \\
\hline
\end{tabular}

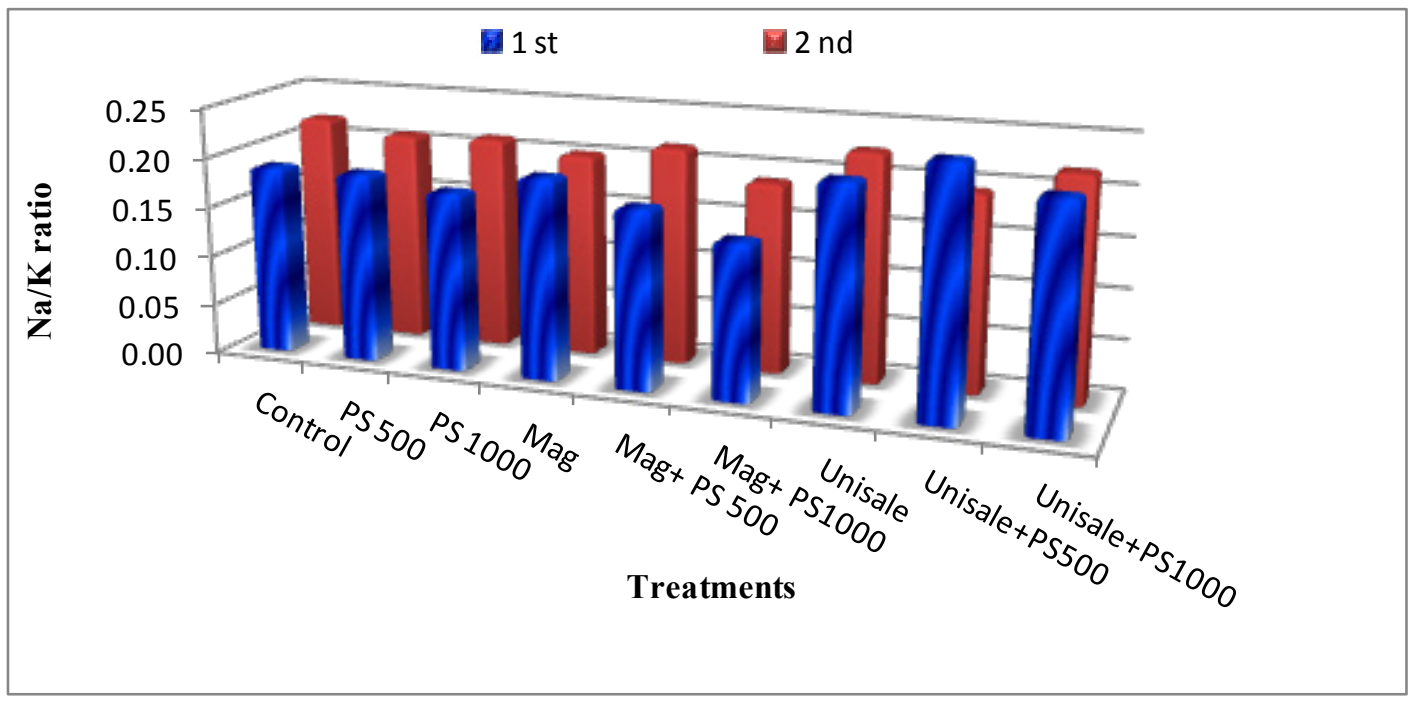

Fig.1. Effect of some applications on $\mathrm{Na} / \mathrm{K}$ ratio of Murcott mandarin leaves in the two experimental seasons.

In this respect, plants experincing salinity/ water stress in their roots zone respond physiologically by regulating their metabolism to adjust to the adversse conditions. As a consequence, a number of low moleculare weight products such as proline, betaine, polyols, polyamines, and sugar accumulate (Naqvi et al., 1994). By increasing salinity,proline content in leaves of mandarin seedlings (Citrus reticulata L.) were increased (Elazab , 2016).

\section{Root distribution.}

Data in Table 8 demonstrated the effect of the tested treatments on root horizontal, vertical and the root horizontal/vertical ratio of Murcott mandarin trees. The results showed that all potassium silicate treatments either solely or in combination with magnetite resulted in the highest values of root horizontal extension. However, Magnetite and Unisale resulted in the higher values of root vertical extension. These results showed that the tested treatments increased the root excavation area both horizontally and vertically which not only helps in avoiding plant water and/or salt stress but also enhanced the plant growth and production.

In this respect, $\mathrm{Si}$ is accumulated primarily in epidermal tissue inboth roots and leaves as polymerized silicagel and itis associated with pectin and calcium ions (Waterkeyn et al., 1982). The thickening epidermal silicon-cellulose layer supports mechanical stability of plants and can increase plant resistance against salt and drought stresses (Epstein, 1999). 
TABLE 8. Effect of some applications on root parameters of Murcott mandarin trees at the end of second experimental season.

\begin{tabular}{lccc}
\hline \multirow{2}{*}{ Treatments } & \multicolumn{3}{c}{ Root parameters } \\
\cline { 2 - 4 } & \multicolumn{2}{c}{$\begin{array}{c}\text { Horizontal roots extension } \\
(\mathbf{c m})\end{array}$} & $\begin{array}{c}\text { Vertical root extension } \\
(\mathbf{c m})\end{array}$ \\
\hline Control & \multicolumn{2}{c}{ second season } \\
PS 500 ppm & $73.33 \mathrm{c}$ & $51.67 \mathrm{c}$ & $1.42 \mathrm{c}$ \\
PS 1000 ppm & $86.66 \mathrm{~b}$ & $56.67 \mathrm{~b}$ & $1.53 \mathrm{~b}$ \\
Mag & $95.00 \mathrm{a}$ & $55.00 \mathrm{bc}$ & $1.73 \mathrm{a}$ \\
Mag+PS 500 & $91.67 \mathrm{bc}$ & $63.33 \mathrm{a}$ & $1.45 \mathrm{bc}$ \\
Mag+PS 1000 & $115.00 \mathrm{a}$ & $61.67 \mathrm{ab}$ & $1.86 \mathrm{a}$ \\
Unisale & $116.67 \mathrm{a}$ & $65.00 \mathrm{a}$ & $1.79 \mathrm{a}$ \\
Unisale+PS 500 & $91.67 \mathrm{bc}$ & $56.67 \mathrm{~b}$ & $1.62 \mathrm{~b}$ \\
Unisale+PS 1000 & $96.67 \mathrm{~b}$ & $61.67 \mathrm{ab}$ & $1.57 \mathrm{~b}$ \\
\hline
\end{tabular}

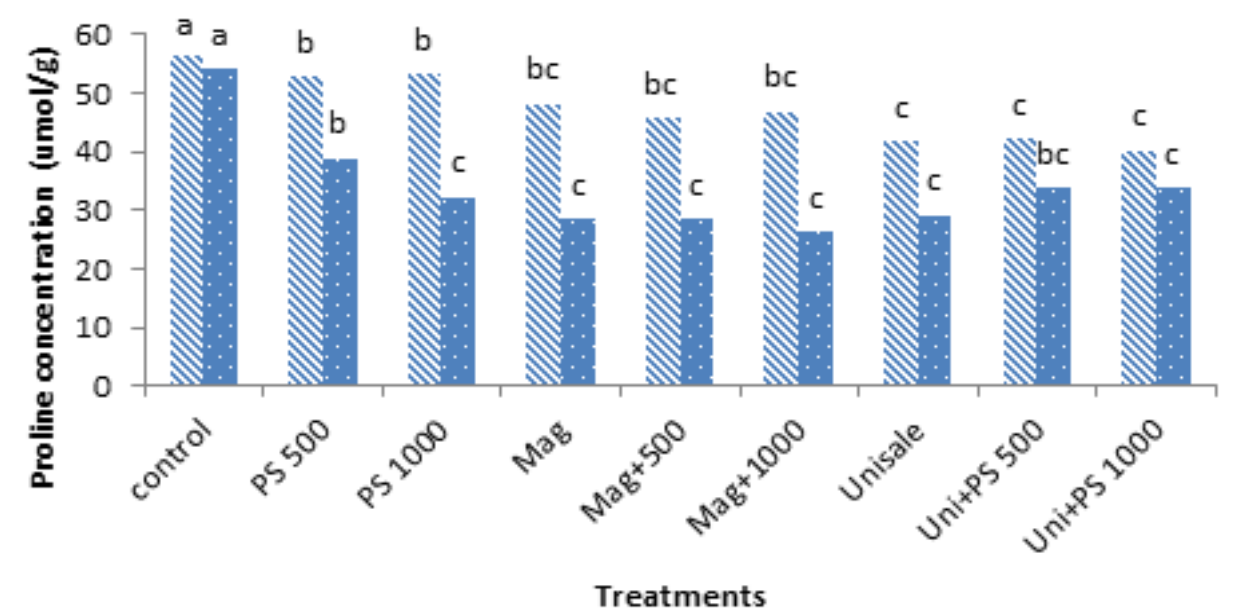

N First season Gecond season

Fig. 2. Effect of some applications on proline concentration of Murcott mandarin leaves in the two experimental seasons.

Soil pH of rhizosphere at the end of second seasons

Data in Fig. 3 illustrated the effect of different applications on $\mathrm{pH}$ values in tow layers $(0-30$ and $30-60 \mathrm{~cm})$. Few differences were observed between soil $\mathrm{pH}$ values in the first layer compared with the initial soil $(\mathrm{pH}$ before starting the experiment $=7.81$ ). Exclusively application of Magnetite raised $\mathrm{pH}$ value to 7.91 in contrast to solely addition of Unisale which decreased its value to 7.67. The main difference was observed in second layer, where, all treatments decreased
$\mathrm{pH}$ value by 6.2 and $4.01 \%$ for PS at 500 and $1000 \mathrm{ppm}$ and around $3.5 \%$ for other treatments compared with initial $\mathrm{pH}$ value of the second layer (7.97). Although, potassium silicate is the only foliar treatment against other treatments which added to soil, the highest reduction in soil $\mathrm{pH}$ was observed in both rates of PS treatments. Silicon provided nutrient uptake of citrus trees and increases roots extension, respiration, discharge and there exudates which can decrease $\mathrm{pH}$ value of rhizosphere zone. These data are in the same line with those obtained by Matichenkov et al. (2000). 


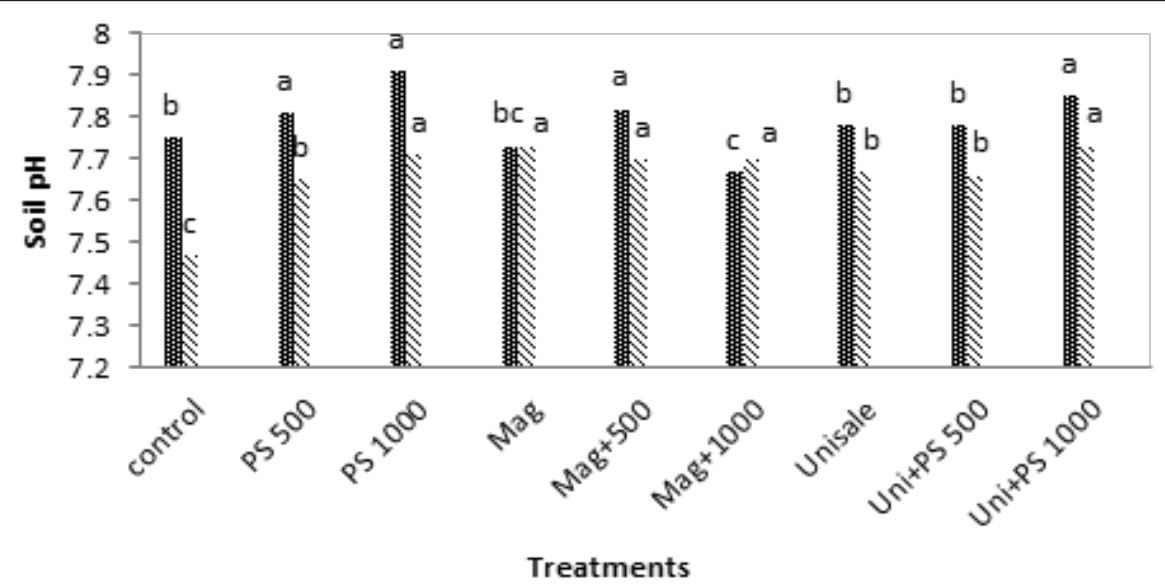

眀 $\mathrm{pH}$ at 0-30 cm soil depth $\quad \mathbb{N} \mathrm{pH}$ at $30-60 \mathrm{~cm}$ soil depth

\section{Fig. 3. Effect of some applications on soil $\mathrm{pH}$ at end of the second experimental season}

Electrical conductivity of rhizosphere at the end of second season.

Under studied soil condition suffering from lack of texture and structure, fast leaching, very poor biological activities, organic matter content thus fertility. The electrical conductivity of the two layers 0-30 $\mathrm{cm}(\mathrm{A})$ and 30-60 $\mathrm{cm}$ (B) under all treatments were lowered than the initial value $(6.1$ and $3.7 \mathrm{dSm}^{-1}$ for surface and subsurface layers) as illustrated in Fig. 4. The highest reduction in EC value was observed in control treatments this may be due to:

- There isn't any addition to control. The soil amendments raise soil EC value especially under drip irrigation system which allows dissolving additive amendments slowly.

- Both of horizontal and vertical root extension is low in control as described in Table 8, so that the chemical and biological activity in rhizosphere is limited which can decrease EC value.
Although, potassium silicate was added as foliar application, the highest $\mathrm{EC}$ value was observed in both rates of PS. As presented in Table 8 all treatments that contained PS resulted in high root extension and this may be reflect the high chemical and biological activity in root zone and high root exudates that enhance soil hydrophysical properties therefore increasing soil aggregates and subsequently decreasing leaching process and losing nutrients. Irrespective of control, EC values of surface layer were decreased by 54.4 , 65.6, 51.6, 58.2, 65.9, 65.2, 64.8 and $64.9 \%$ for PS 500 ppm, PS 1000 ppm, Mag, Mag + PS 500 ppm, Mag+PS 1000 ppm, Unisale, Unisale + PS 500 and Unisale + PS 1000 ppm compared to initial EC value $\left(6.1 \mathrm{dSm}^{-1}\right)$, respectively. This depression refers to not only different treatments but also the quantity and quality of irrigation water as well as good drainage system. Generally salinity decrease in surface layer was higher than subsurface one. These findings are nearly in line with those obtained by Ali et al. (2013).

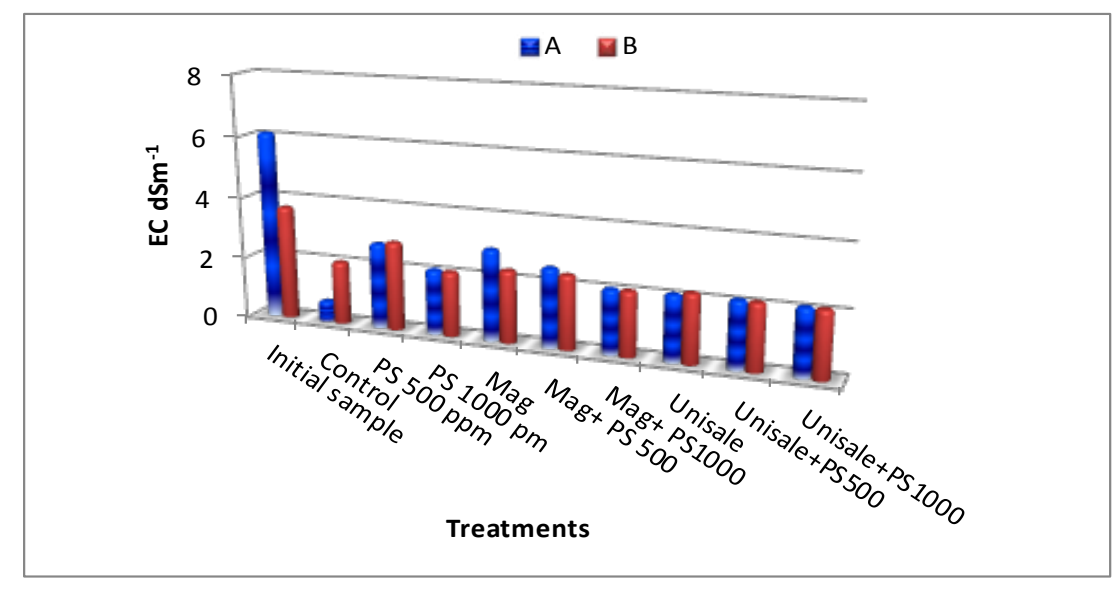

Fig. 4. Effect of some applications on soil $\mathrm{EC}\left(\mathrm{dSm}^{-1}\right)$ at end of the second experimental season.

Egypt. J. Hort. Vol. 44, No. 2 (2017) 


\section{Conclusion}

Salinity stress on Murcott trees grown in saline sandy soil can be alleviated by treatments with Unisale, potassium silicate followed by Magnetite as sole application or in combinations. These different treatments led to increasing fruit yield, its quality and the root distribution, as well as photosynthetic pigments and mineral status of leaves.

Acknowledgements: Sincere gratitude is due to Citrus Research Department, Horticulture Researh Institute and to Soils and Water Use Department, National Research Centre.

Funding statements: No external funding suppod this research

Conflicts of interest: The authors have declared no competing interests

\section{References}

A.O.A.C. (1995) "Association of Official Agricultural Chemists”, $9^{\text {th }}$ ed., Washington DC, USA., pp.490-510

Abou-Baker N.H., Abd-Eladl, M. and Abbas M.M. (2011) Use of silicate and different cultivation practices in alleviating salt stress effect on bean plants. Australian Journal of Basic and Applied Sciences, 5 (9), 769-781.

Abou-Baker N.H., Abd-Eladl, M. and Eid, T.A. (2012) Silicon and water regime responses in bean production under soil saline condition. Journal of Applied Sciences Research, 8 (12), 5698-5707.

Agarie, S. (1996) Function of silica bodies in epidermal system of rice (Oryza sativa L.). Journal of Experimental Botany, 47, 655 - 660.

Ahmed, F.F., Gobara, A.A. and El-Dawwey, G.M. (1996) Response of Balady mandarin trees grown on new reclaimed sandy soil to spraying boron. Proc. of $4^{\text {th }}$ Arabic conf. for Hort. Crops, El-Minia, Egypt Part 11, Pomology, 1009-1018.

Ali, M.A., El-Gendy, R.S.S. and Ahmed, O.A. (2013) Minimizing adverse effects of salinity in vineyards.J. Hort. Sci. Ornamen. Plants, 5 (1), 12-21.

Bates, L.S., Waldren, R.P. and Teare, I.D. (1973) Rapid determination of free proline for water-stress studies. Plant and soil, 39 (1), 205-207.

Cottenie, A., Verloo, M., Kiekens, L., Velghe, G. and Camerlynck, R. (1982) "Chemical Analysis of Plants and Soils”. Lab. Agroch. State Univ. Ghent, Belgium.
Datnoff, L.E., Snyder, G.H. and Korndorfer, G.H. (2001) "Silicon in agriculture". Amsterdam: Elsevier Science.

Dhawi, F. and Al-Khayri J.M. (2008) Proline accumulationin response to magnetic fields in date palm (Phonix Dactylifera L.), Open Agric. J., 2, 8083.

Duncan, D.B. (1955) Multiple range and multiple F. Tests Biometrics, 11, 1-24.

Elazab, D.S. (2016) Extended antioxidants induced effects on mandarin seedlings (Citrus reticulata $\mathrm{L}$.) growth and physiological parameters under saline irrigation conditions. American-Eurasian J. Agric. and Environ. Sci., 16 (2), 362-373.

Epstein, E. (1999) Silicon. Annu. Rev. Plant Physiol. Plant Mol. Biol., 50, 641- 664.

Erdoghan, G.D. (2003) Influence of calcium deficiency on superoxide Generating-NADPH oxidant defense systems in Bean root cells. Master of Science, Sabanci University.

Fatma, A. Kotb and Abd-Eladl M. (2017) Effect of silica compounds on vegetative growth, yield, fruit quality and nutritional Status of Olinda Valencia orange. Middle East Journal of Agriculture Research, 6 (1), 45-56

Fidalski, J., Auler, P.A.M. and Tormem, V. (2000) Relations among Valencia orange yields with soil and leaf nutrients in northwestern Parana, Brazil Brazilian Archives of Biology and Technology, 43 (4), 387-391.

Ganeshamurthy, A.N.,Satisha, G.C. and Prakash, P. (2011) Potassium nutrition on yield and quality of fruit crops with special emphasis on banana and grapes. Karnataka J. Agric. Sci., 24 (1), 29-38.

Hopkins, W.G. (2006) Plant nutrition. New York, United States of America, 144p.

Hussein M.M., El-Saady A.M. and Abou-Baker N.H. (2015) Castor bean plants response to phosphorus sources under irrigation by diluted seawater. International Journal of Chem. Tech. Research, 8 (9), 261-271

Hwang, S.J., Park, H.M. and Jeong, B.R. (2005) Effect of potassium silicate on the growth of miniature rose 'Pinocchio' grown on rock wool and its cut flower quality. Journal of the Japanese Society for Horticultural Science, 74, 242 - 247.

Ibrahim, H.I.M. and Al-Wasfy, M.M. (2014) The promotive impact of using silicon and selenium with potassium and boron on fruiting of Valencia Egypt. J. Hort. Vol. 44, No. 2 (2017) 
orange trees grown under Minia region conditions. World Rural Observ., 6 (2), 28-36.

Jackson, L.K. (2001) Citrus nutrition highlights. Citrus Industry, $14-15 \mathrm{p}$.

Jia, Z.R., Yi, L. and Xuan, Q.N. (1998) Effects of B and $\mathrm{Ca}$ on photosynthetic physiology and root vigour in lemon (Citrus limon) seedlings. J. Southwest Agric. Univ., 20 (4), 315-320.

Jones, W., and Embleton, T.W. (1960) "Leaf analysisnitrogen control program for oranges". California Citrograph, $45 \mathrm{p}$.

Khan, H.R.,Elahi, S.,Hussain, M.S. and Adachi, T. (1994) Soil characteristics and behavior of potassium under various moisture regimes.Soil science and plant nutrition, 40 (2), 234 - 254.

Kishor, P., Hong, Z., Miao, G.H., Hu, C. and Verma, D. (1995) Over expression of [delta]-Pyrroline -5- Carboxylate Synthetase Increases Proline Production and Confers Osmotolerance in Transgenic Plants. Plant Physiology, 108 (4), 13871394.

Klute, A. (1986) "Methods of Soil Analysis" Part I: Physical and mineralogical Methods. $2^{\text {nd }}$ ed., Amer. Soc. Agron. Monograph No. 9, Madison, Wisconsin, U.S.A.

Ladaniya, M.S. (2008) "Citrus fruit Biology, Technology and Evaluation". First Edition San Diego, USA., 558 p.

Lalithya, K.A., Bhagya, H.P. and Choudhary, R. (2014) Response of silicon and micro nutrients on fruit character and nutrient content in leaf of Sapota. Biolife, 2 (2), 594-598.

Levent Tuna, A., Cengiz, K., David, H., Bernardo, M. A., Salih, A. and Ali, R.G. (2008) Silicon improves salinity tolerance in wheat plants. Environmental and experimental Botany, 62, 10-16.

Liang, Y.C. (1999) Effects of silicon on enzyme activity and sodium, potassium and calcium concentration in barley under salt stress. Plant and Soil, 209, 217 224.

López-Lefebre, L.R., Ruiz, J.M.,Rivero, R.M., García,E. Sánchez, P.C. and Romero, L. (2002) Supplemental boron stimulates ammonium assimilation in leaves of tobacco plants (Nicotianatabacum L.)Plant Growth Regulation Reg., 36, 231-236.

Ma, J.F. and Yamaji, N. (2006) Silicon uptake and accumulation in higher plants.Trends in Plant Sci., 11, 392-397.
Ma, J.F., Mitani, N., Nagao, S.,Konishi, S.,Tamai, K., Iwashita, T. and Yano, M. (2004) Characterization of the silicon uptake and molecular mapping of the silicon transporter gene in rice. Plant Physiology, 136, 3284-3289.

Mansour, E.R., (2007) Effect of some culture practices on cauliflower tolerance to salinity under Ras Suder conditions. MSc. Thesis., Fac. Agric., Horticulture Dept. Ain Shams Univ.

Matichenkov, V.V., Calvert, D.V. and Snyder, G.H. (2000) Prospective of silicon fertilization for citrus in Florida. Proc. Soil Crop Sci. Soc. Florida, 59, 137-141.

Mervat A., Ali, Rafaat S. El-Gendy, S. and Ola A. Ahmed (2013) Minimizing adverse effects of salinity in vineyards. Journal of Horticultural Science and Ornamental Plants, 5 (1), 12-21.

Naqvi, S.S.M., Mumtaz, S., Shereen, A. and Khan, M. A. (2002) Comparative performance of two methods for proline estimation in wheat. Pakistan Journal of Botany, 34, 355-358.

Naqvi, S.S.M., Mumtaz, S.and Ansari, R. (1994) Prospects for developing stress tolerant plantsfrom biotechnological methods. Pak. J. Agric. Res, 15 , 185-194.

Newman, E.I. (1966) A method of estimating the total length of roots in sample. Appl. Ecol., 3, 139-145.

Nornai, R. (1982) Formula for determination of chlorophyllous pigments extracted with N.N Dimethyl formamide. Plant Physiol, 69, 13711381.

Obreza, T.A. (2003) Importance of potassium in a Florida citrus nutrition program. Beterr Crops, 87 (1), 19-22.

Page, A.L., Miller, R.H. and Keeney, D.R. (1982) "Methods of Soil Analysis", part 2. Chemical and microbiological properties. Amer. Soc. of Agron, Madison, Wisconsin, USA.

Peter, K.H. (2005) Calcium: A central regulator of plant growth and development. J. Plant Cell, 17 (8), 2142-2155.

Plieth, C. (2005) Calcium: Just another regulator in the machinery of life. Ann. Bot., 96, 1-8.

Reezi, S., Babalar, M. and Kalantari, S. (2009) Silicon alleviates salt stress, decreases malondialdehyde content and affects petal color of salt-stressed cut rose (Rosa xhybrida L.) 'Hot Lady'. African Journal of Biotechnology, 8 (8), 1502-1508. 
Romero-Aranda, M.R., Jurado, O. and Cuartero, J. (2006) Silicon alleviates the deleterious salt effect on tomato plant growth by improving plant water status. Journal of Plant Physiology, 163, 847-855.

Saure, M.C. (2005) Calcium translocation to fleshy fruit: its mechanism and endogenous control. Scientia Hort., 105, 65- 89.

Shu, L.Z. and Liu, Y.H. (2001) Effects of silicon on growth of maize seedlings under salt stress.AgroEnvironmental Protection, 20, 38-40.

Snedecor, G.W. and Cochran, W.G. (1980) "Statistical Methods", $6^{\text {th }}$ ed. Iowa State Univ., Amess.Lowa.

Snyder, G.H., Matichenkov, V.V. and Datnoff, L.E. (1999) “Handbook of Plant Nutrition", pp.: 551568.

Spiegel-Roy, P. and Goldschmidt, E. (2008) "Biology of Citrus”. Cambridge University Press, pp.:140-184.
Thippeshappa, G.N., Ravi, C.S. and Ramesha, Y.S. (2014) Influence of soil and foliar application of silicon on vegetative characters, fruit yield and nutrients content of sapota leaf. Research on Crops, 15 (3) 626.

Turan, M.A., Turkmen, N. and Taban, N. (2007) Effect of $\mathrm{NaCl}$ on stomatal resistance and proline chlorophyll, $\mathrm{Na}, \mathrm{Cl}$ and $\mathrm{K}$ concentration of lentil plants. J. Agron., 2, 378-381.

Waterkeyn, L., Bientait, A., and Peeters, A. (1982) Callose et silice epidermiques rapports avec la transpiration culticulair. La Cellule., 73, 263-287.

White, P.J. (2000) Calcium channels in higher plants. Biochem. Biophys. Acta, 1465, 171-189.

Zhu, J.K. (2001) Plant salt tolerance.Trends Plant Sci., 6, 66-71.

Zhu, Z., Wei, G., Li, J.,Qian, Q. and Yu, J. (2004) Silicon alleviates salts stress and increases antioxidant enzymes activity in leaves of saltstressed cucumber (Cucumis sativus L.)Plant Science, 167, 527-533.

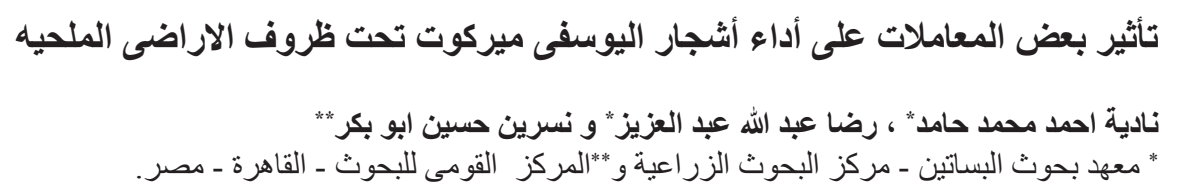

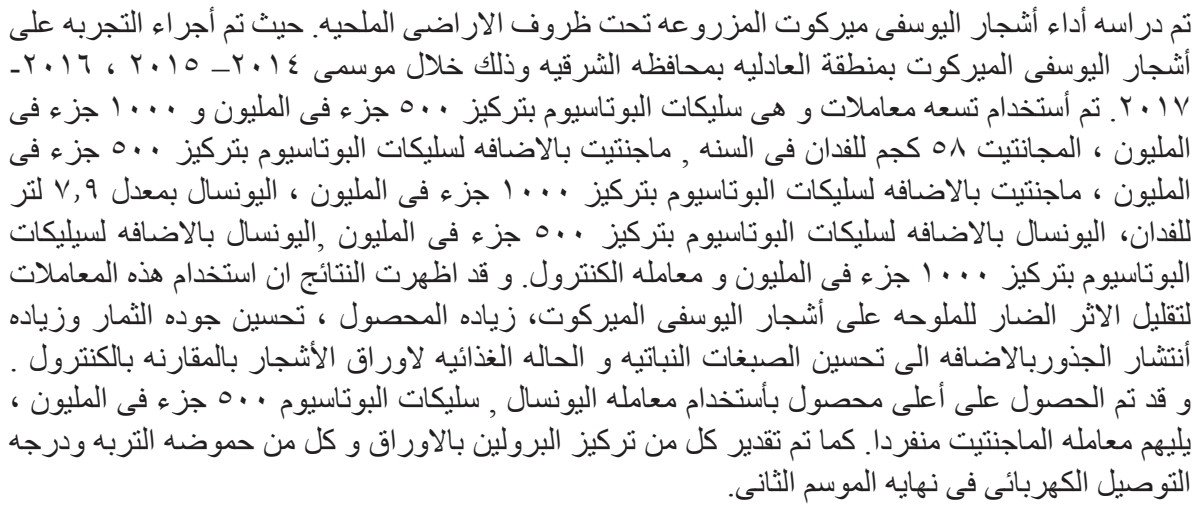

